Hasan ef. Makić, prof.

\title{
OSNIVANJE ISLAMSKE PEDAGOŠKE AKADEMIJE U BIHAĆU
}

Sažetak

Rad obrađuje okolnosti u kojim je došlo do osnivanja Islamske pedagoške akademije, danas Islamskog pedagoškog fakulteta u Bihaću, te spominje značajne datume $i$ osobe koje su na svojim plećima iznijele osnivanje ove jedinstvene visokoobrazovne ustanove na području Unsko-sanskog kantona.

Rad navodi dijelove elaborata o opravdanosti osnivanja ove institucije na ovim područjima na osnovu čega je Sabor Islamske zajednice u BiH donio odluku o njenom osnivanju.

Rad se osvrće i na probleme na koje je ova institucija nailazila neposredno nakon njenog osnivanja, te sa ponosom podsjeća na nastavni kadar koji je na svojim plećima iznio teret organizovanja nastavnog procesa.

Završetkom agresije na Bosnu i Hercegovinu i stvaranjem osnovnih uvjeta planskog razvoja, Islamska zajednica se orijentisala na rješavanje prioriteta nastalih demokratskim promjenama a jedan od tih prioriteta bio je osposobljavanje stručnog kadra za predmet Islamska vjeronauka, uveden u nastavni proces na području tadašnjeg Bihaćkog okruga u školskoj 1992/1993. godini.

Naime, na inicijativu nekoliko entuzijasta, zbog agresijom pokidanih veza sa rukovodstvom Islamske zajednice u Sarajevu, 1992. godine formiran je Sabor Islamske zajednice Okruga Bihać, za čije djelovanje je izdao saglasnost i tadašnji predsjednik Vrhovnog sabora Islamske zajednice Mustafa Plićanić. Sabor je imao brojne aktivnosti, veoma značajne za taj period. Ovdje ćemo posebno izdvojiti osnivanje Medrese "Džemaluddin ef. Čaušević" u Cazinu i uvođenje vjeronauke u osnovne i srednje škole.

U oktobru 1992. godine Sabor je podnio zahtjev Vladi Okruga Bihać da se u osnovne i srednje škole uvede predmet vjeronauke, ali 
pod nazivom Islamska kultura i civilizacija (IKC), kako bi bila bolje prihvaćena.

Vlada Okruga je prihvatila ovaj zahtjev i od tada se IKC izučava kao obavezan predmet od petog do osmog razreda u osnovnim školama i svim razredima srednje škole.

Vjeronauku su predavali uglavnom imami, tako da je od 106 tada zaposlenih imama na području Bihaćkog muftijstva njih 76 bilo angažirano i na predavanju vjeronauke u školama. Pored njih nastavu je izvodilo još 17 predavača koji su završili medresu, ali nisu zaposleni u Islamskoj zajednici.

Zbog nedostatka kadra za izvođenje nastave, vjeronauka u osnovnim školama 1992. god. nije uvedena od prvog, nego tek od petog razreda. Tek je u školskoj 1995/1996. god. vjeronauka uvedena od prvog razreda. Nedostajalo je oko 60 predavača vjeronauke.

$\mathrm{S}$ druge strane, bilo je neophodno da se razdvoji imamski posao od posla vjeroučitelja i da se za vjeronauku pripreme kadrovi sa višom i visokom stručnom spremom. Stoga je Muftijstvo bihaćko pokrenulo inicijativu za osnivanje Islamske pedagoške akademije (IPA) u Bihaću, po uzoru na već postojeću akademiju u Zenici. U tu svrhu je u oktobru 1995. god. izradilo elaborat o opravdanosti otvaranja IPA u Bihaću i uputilo ga Rijasetu Islamske zajednice. U elaboratu je izneseno stanje vezano za pitanje vjeronauke i razlozi neophodnosti osnivanja jedne visokoškolske institucije za obrazovanje stručnih kadrova za predmet vjeronauke. Ovdje ćemo navesti najznačajnije navode iz pomenutog elaborata.

"Prema popisu stanovništva iz 1991. godine na području Bihaćkog muftijstva (općine Bihać, Cazin, V. Kladuša, Bos. Krupa, Bos. Novi, Prijedor, Sanski Most, Bos. Petrovac i Ključ) živjelo je 314.160 muslimana. Dodamo li tome one stanovnike koji su se izjasnili kao Jugosloveni i ostali, a koji su također uglavnom muslimani, a bilo ih je 22.712, onda to sve skupa iznosi 336.872 pripadnika muslimanskog naroda.

Do izbijanja rata 1992. godine na području muftijstva bilo je 299 osnovnih škola (centralne i područne škole) i 29 srednjih škola sa 66.952 đaka u osnovnim i 14.932 u srednjim školama. Ako znamo da je na ovom području živjelo oko $68 \%$ muslimana i ostalih, onda to iznosi 47.300 učenika muslimana u osnovnim i 10.300 u srednjim školama. 
Ratna stradanja, genocid i progoni bošnjačkog stanovništva značajno su umanjili ove brojke. Međutim, proces njegovog povratka hvala Allahu dž.š. već je uveliko počeo tako da se nadamo da će se veliki dio stanovništva polahko vraćati svojim ognjištima /.../. Nadamo se da svi ovi pokazatelji jasno govore u prilog naše procjene o potrebi otvaranja Islamske pedagoške akademije u Bihaću."

Dalje se u elaboratu navodi kako bi se osnivanjem akademije omogućilo postepeno isključivanje imama iz procesa nastave i njihovo vraćanje u džemate pa se u obrazloženju toga kaže:

"Kako se iz dosadašnjeg teksta vidi najveći broj predavača islamske vjeronauke sada su imami, kojima je osnovno zanimanje posao imama u džematu. Uz svu dobru volju da se angažuju u školi, nerijetko se dešava da imama određene obaveze u džematu spriječe da prisustvuje nastavi. Svakako da ima i onih koji neopravdano odsustvuju sa nastave što sve skupa ne ostavlja najpovoljniji dojam. Zato bi najoptimalnije rješenje bilo postepeno većinu imama osloboditi ove obaveze, a u škole uvoditi za po pripremljene i osposobljene kadrove."

Osim toga $u$ elaboratu se ukazuje na mogućnost doškolovavanja imama, jer bi otvaranje akademije motivisalo jedan broj imama sa ovog područja Republike Bosne i Hercegovine da studijem uz rad stiče više zvanje i kvalifikacije, posebno ako bi takav rad bio praćen i drugim stimulativnim mjerama Zajednice.

U elaboratu se navodi i procjena o povećanju broja učenika u Bosni i Hercegovini, kao i povećanju broja vjeroučitelja i citira dugoročni program razvoja osnovnog obrazovanja i vaspitanja u Bosni i Hercegovini donesen u Sarajevu februara 1992. god. a u kojem se, između ostalog, kaže:

"Uvede li se obavezna vjerska nastava po jedan sat tjedno, onda će to u startu povećati broj nastavnika za još 2.583 nastavnika. $\mathrm{Na}$ kraju planskog perioda 2010 godine trebat će ukupno 6.000 nastavnika za vjersku nastavu. Uzme li se u obzir činjenica da su Bošnjaci do rata predstavljali skoro polovicu ukupnog broja stanovništva Bosni i Hercegovini, onda to znači da bi oko 3.000 nastavnika vjeronauke bilo potrebno da radi na predmetu islamske vjeronauke."

$\mathrm{Na}$ kraju se u elaboratu, $\mathrm{u}$ prilog potrebe osnivanja IPA u Bihaću, navodi i tvrdnja da bi se time povećao procenat studenata sa područja Unsko-sanskog kantona, do rata porazan, pa se navodi da je 
na 10.000 stanovnika Sarajevo imalo 244 studenta, Banja Luka 80, Mostar 92, Zenica 92, Doboj 50, Bihać 38, Cazin 14, Drvar 56, Bos. Krupa 28 a Velika Kladuša samo 12 studenata. Ovo su podaci Statističkog godišnjaka BiH za 1984. godinu.

Elaborat je predočen članovima Rijaseta. O inicijativi za osnivanje IPA u Bihaću raspravljalo se na sjednici Rijaseta održanoj u Bihaću 16.11.1995. godine. Tom prilikom sam i usmeno obrazložio inicijativu. Nakon toga Rijaset ju je prihvatio i proslijedio Saboru Islamske zajednice na usvajanje.

Na svojoj redovnoj sjednici održanoj u Zenici 23. decembra 1995. godine Sabor je prihvatio prijedlog Rijaseta i donio odluku o osnivanju Islamske pedagoške akademije u Bihaću.

Na narednoj sjednici Sabora održanoj u Sarajevu 5. juna 1996. god. imenovan je Upravni odbor Akademije u sastavu:

Hasan Makić, predsjednik

Mirsad Veladžić, član

Mehmed Mašić, član

Enes Ljubijankić, član

Šefik Štulanović, član

Teufik Sedić, član

Nurija Kazaferović, član

Atif Vučkić, član

Alaga Ajdinović, član

Na svojoj prvoj sjednici Upravni odbor je usvojio pravila Akademije, izabrao prof. Muharema Štulanovića za dekana Akademije a za sekretara je izabran dipl. pravnik Mehmed Duraković.

Od tada pa do upisa prve generacije studenata 1996/97. godine novoizabrano rukovodstvo Akademije vršilo je opsežne pripreme da bi se početak akademske godine dočekao što spremnije.

Teškoća je bilo od samoga početka. Trebalo je adaptirati zgradu Bihaćkog muftijstva, gdje je bio planiran privremeni smještaj Akademije do preseljenja u vlastiti prostor, osigurati nastavni kadar, opremu i osnovne uslove za kvalitetan nastavni proces. Formiranje jezgra nastavnog kadra za početak izvođenja nastave nije bilo jednostavno. Pored dvojice profesionalno angažiranih profesora, dr. Muharema Štulanovića i dr. Fuada Sedića, u nastavni proces je uključeno i nekoliko profesora sa IPA iz Zenice i to dr. Nusret 
Isanović, dr. Safvet Halilović, dr. Šefik Kurdić i dr. Refik Ćatić. Angažiran je zatim i dr. Sead Misirlić iz Banje Luke, a iz Zagreba dr. Sulejman Mašović, dr. Remzija Hadžiefendić-Parić i Lamija Kulenović. Također su uključeni i neki profesori sa visokoškolskih ustanova u Bihaću: dr. Ratmira Pjanić i dr. Ramo Atajić te asistent Asim Koričić. Ja sam od početka, kao vanjski saradnik, predavao arapski jezik.

Nakon raspisanog konkursa, kvalifikacioni ispit za prijem prvih studenata održan je 26. avgusta 1996. godine. Primljeno je 26 redovnih i 30 vanrednih studenata, a nastava je zvanično počela 14. decembra 1996. godine. Ove datume namjerno spominjem jer oni predstavljaju historijske međaše kada je u pitanju osnivanje Islamske pedagoške akademije u Bihaću.

Kasniji razvoj Akademije, izgradnja i preseljenje u vlastitu zgradu i prerastanje u Islamski pedagoški fakultet, kao i rezultate koje je do sada postigla, teme su o kojima bi trebalo posebno pisati. Ovoga puta cilj mi je bio podsjećanje na samo osnivanje ove veoma značajne visokoškolske ustanove, članice Bihaćkog univerziteta i obrazovne ustanove Islamske zajednice. 
HASAN MAKIĆ, B.A.

\section{FOUNDING OF ISLAMIC PEDAGOGICAL ACADEMY IN BIHAĆ}

\section{SUMMARY}

This work deals with circumstances at the time of founding Islamic Pedagogical Academy, today Islamic Pedagogical Faculty in Bihać. It mentions important dates and people who bore the brunt of founding of this unique institution of higher education in the region of Una - Sana Canton.

The work mentions parts of elaboration of justifiability of founding such an institution in this region on basis of which the Assembly of Islamic Community made the decision about its founding.

The work looks back at problems this institution had just after foundation and proudly remembers the staff that bore the brunt of organizing teaching process. 


\section{الأستاذ حسن ماكينش \\ تأسيس الأكاديمية الإسلامية للتربية في بيهاتش \\ الملخص}

يتتاول هذا البحث ظروف تأسيس أكاديمية التربية الإسلامية في بيهانش، فيذكر أهم

الأحداث و الأشخاص الذين حملوا عبء تأسيس هذه مؤسسة تعليمية وحيدة من نوعها في منطفة أونسكو سانسكي.

يورد البحث بعض أجزاء دراسة حول مبررات تأسيس الأكاديمية في هذه المنطقة

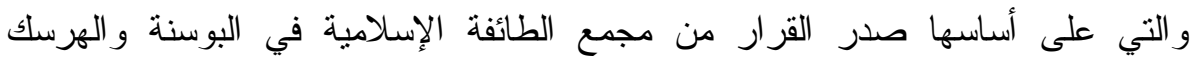
القاضي بتأسيسها.

يلفت البحث نظر القارئ إلى الصعوبات التي واجهتها الأكاديمية بُعَيََْ تأسيسها، ويذكر بكل فخر أسماء المدرّسين الذين حملوا عبء تتظيم العملية التعليمية. 